\title{
PRELIMINARY ASSESSMENT OF THE EFFECTS OF BLAST DESIGN FACTORS ON FRAGMENTATION AT LAFARGE KANTHAN LIMESTONE QUARRY, CHEMOR, PERAK
}

\author{
Shaib Abdulazeez Shehu ${ }^{1,2}$, Mohd Hazizan Mohd Hashim ${ }^{*}$, and Nur Aliah Hazirah \\ Awang Kechik ${ }^{1}$
${ }^{1}$ Strategic Mineral Niche, School of Materials and Mineral Resources Engineering, Universiti Sains Malaysia, Penang, Malaysia, Tel. +60123551691,*e-mail: mohd_hazizan@usm.my
${ }^{2}$ Department of Mineral and Petroleum Resources Engineering, School of Engineering, Kogi State Polytechnic, Lokoja, Nigeria, Tel. +2348036553412, e-mail: shehu@ student.usm.my

Received Date: September 19, 2018; Revised Date: March 22, 2020; Acceptance Date: July 13, 2020

\begin{abstract}
The results of blasting affect every other downstream operation in quarrying and mining process. Factors influencing blast results can be classified as either controllable or non-controllable. If desired fragmentation is to be obtained, the controllable factors (blast geometry and explosive properties) must be sufficiently designed to match the non-controllable ones (geological factors and legislative constraints). This study investigates the influence of blast design parameters on rock fragmentation. Six different blast designs were studied and analyzed. Rock samples were obtained from each face to evaluate the uniaxial compressive strength (UCS). Images of muck pile were captured using suitable digital camera. The images were uploaded into the WipFrag software to analyze the fragmentation resulting from the blasting. The particle size distribution of each blast was obtained, and the mean fragment size correlated with the blast design parameters. The percentage cumulative passing for gyratory crusher with the feed size of $1500 \mathrm{~mm}$ ranges between 92.8 to $100 \%$. The stiffness ratio, powder factor and uniaxial compressive strength have high correlation with mean fragment size. The stiffness ratio increases with mean fragment size with a correlation coefficient of 0.89 . The mean fragment size becomes finer with increase in powder factor with a correlation coefficient of 0.76 . Powder factor also has a high correlation with the uniaxial compressive strength of the rock. The higher the uniaxial compressive strength of rock, the higher the powder factor needed for a specified fragment size. In this study, spacing to burden ratio has a very weak correlation with the fragment size. All the studied blast events produced good fragmentation with a uniformity index varying from 2.097 to 2.525 .
\end{abstract}

Keywords: Fragmentation, Powder factor, Stiffness ratio, Uniaxial compressive strength, Uniformity index, WipFrag

\section{Introduction}

Blast parameters are site specifics. The relationship between these factors and the final fragmentation is very crucial in designing a blasting programme. The size of fragment is an important factor to evaluate the efficiency and productivity of blasting [1], [2]. If rock fragmentation is not accessed regularly, production cost and time delay in quarrying process can increase beyond expectation. Drilling and blasting constitute 15 to $20 \%$ of the total mining cost [3], and hence the need to tailor blast design towards optimal results to enhance efficiency of the quarrying process.

If blasting does not generate desired fragment size, there will be an increase in operational cost due to unnecessary secondary blasting and delays in materials handling [4]. 
Good blast result could increase loader and excavator productivity by increasing the bucket and truck fill factors as well as diggability of the excavator [5], [6]. A uniformly sized fragmentation increases crusher and mill throughput and decreases the comminution energy.

If the drilling and blasting cost is increased due to high explosive charge value, costs of subsequent operations will be reduced due to the resulting finer fragments [7]. However, excessive explosive must likewise be avoided to minimize environmental damage and generation of disproportionate fines.

The bench height, burden distance and the powder factor are three core controllable parameters affecting fragmentation distributions. Muckpile shape and fragment size are more sensitive to the burden distance in production bench blasting [8], [9]. The powder factor is essentially determined by the structural properties of the rock like discontinuity, rock strength and lithology etc. [8], [9], [10], [11]. It is however generally believed that an increase in powder factor ensures smaller fragment size if the rock factors are held constant [3], [12].

Singh et al. [13] had observed that mean fragment size increases with bench height and burden distance. For better accuracy, prediction of fragmentation distribution should not be based purely on hypothetical and mechanical perceptive but incorporating practical data from the field along with hypothetical investigation [9], [11]. By this method, a reliable prediction model can be established for the specific site.

\section{Location and Geology of the Study Area}

This study was carried out at Lafarge Kanthan Quarry which is located at Gunung Kanthan in Chemor, Perak. Figure 1a shows the location of Lafarge Quarry in Peninsula Malaysia while $1 \mathrm{~b}$ shows its location in Kanthan.

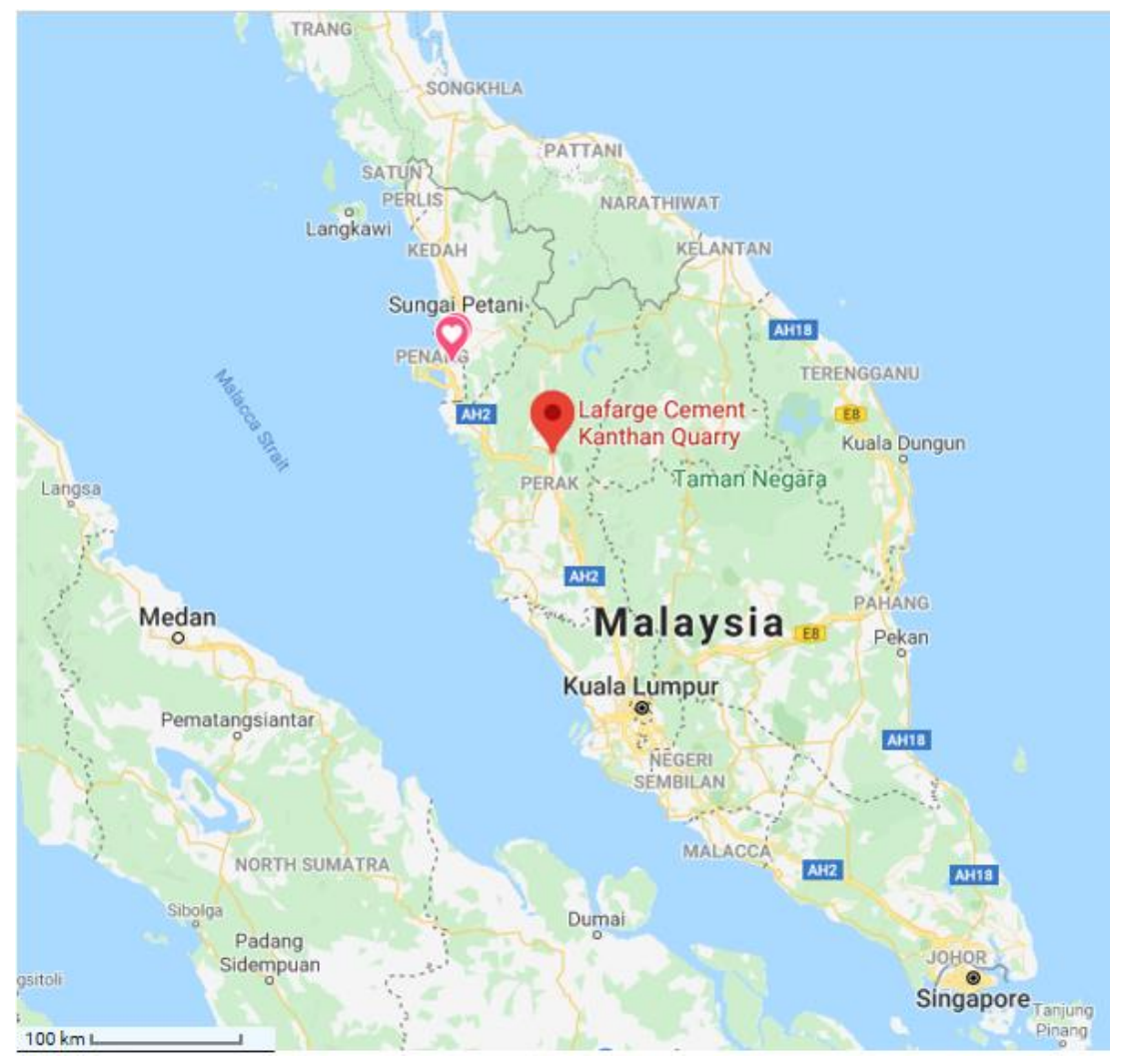

Figure 1a. Location map of the study quarry in Peninsula Malaysia 


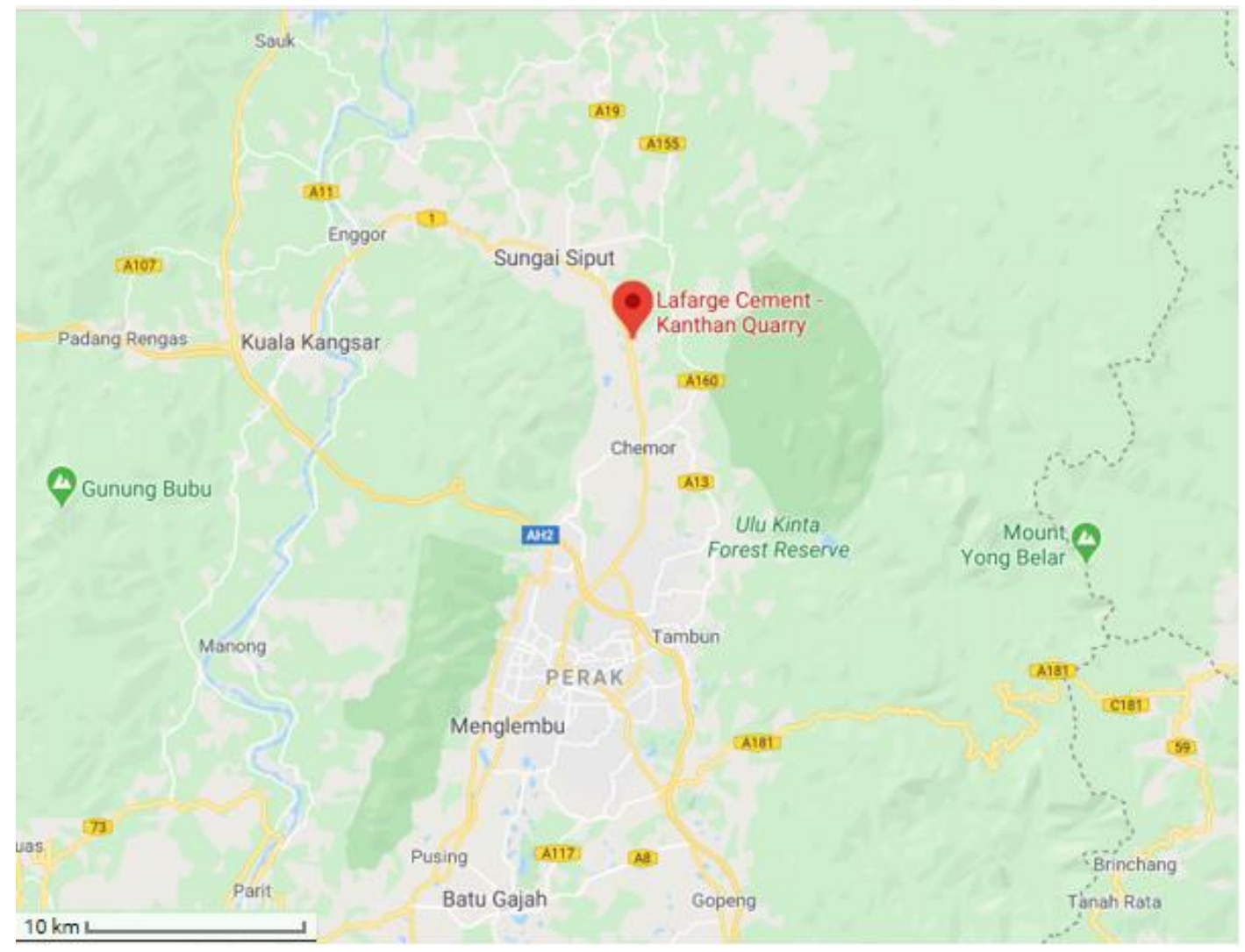

Figure 1b. Location map of the study quarry in Kanthan

The study area has a longitude of $101^{\circ} 06^{\prime} 57.79^{\prime \prime} \mathrm{E}$ and a latitude of $04^{\circ} 46^{\prime} 20.11^{\prime}$ 'N. The closest residential area is about $400 \mathrm{~m}$ away from the quarry. The quarry produces about 4.1 million tonnes of limestone annually for the construction industry in Malaysia.

The quarry is geologically within Kinta Valley which has been dated Devonian to Permian timeline [14]. The limestone includes numerous relatively thin argillaceous beds, exceeding $3000 \mathrm{~m}$ in stratigraphic thickness. Kinta Valley mainly consists of Palaeozoic limestone formations bounded by granitic ridges. Schist is also found at the bottom of the massive limestone body. The limestone is heavily jointed and fractured [15].

\section{Materials and Methods}

Basic blast design parameters were measured for six blast events. After blasting, the muckpile images were taken using suitable camera for fragmentation analysis. Particle size distribution graphs were generated based on the size of fragmented rocks. Rock specimen were collected from each of the working faces for laboratory determination of the strength value. The results obtained from the fragmentation analysis and point load test were analysed and correlated with blast design parameters.

\section{Blast Design Data}

Six blast events were observed and the data for each blast obtained. The blast holes were drilled based on the staggered pattern technique. Bulk explosives were used as the blasting agent with the open cup density of $1.05 \mathrm{~g} / \mathrm{cm}^{3}$. The hole diameter, hole depth, burden, spacing, stemming length and charging density were measured. The blasts were initiated by shock tube system sequencing at $25 \mathrm{~ms}, 42 \mathrm{~ms}$ and $67 \mathrm{~ms}$. Figure 2 shows the cross section of charged blastholes while Figure 3 illustrates a typical firing pattern of Lafarge quarry. 


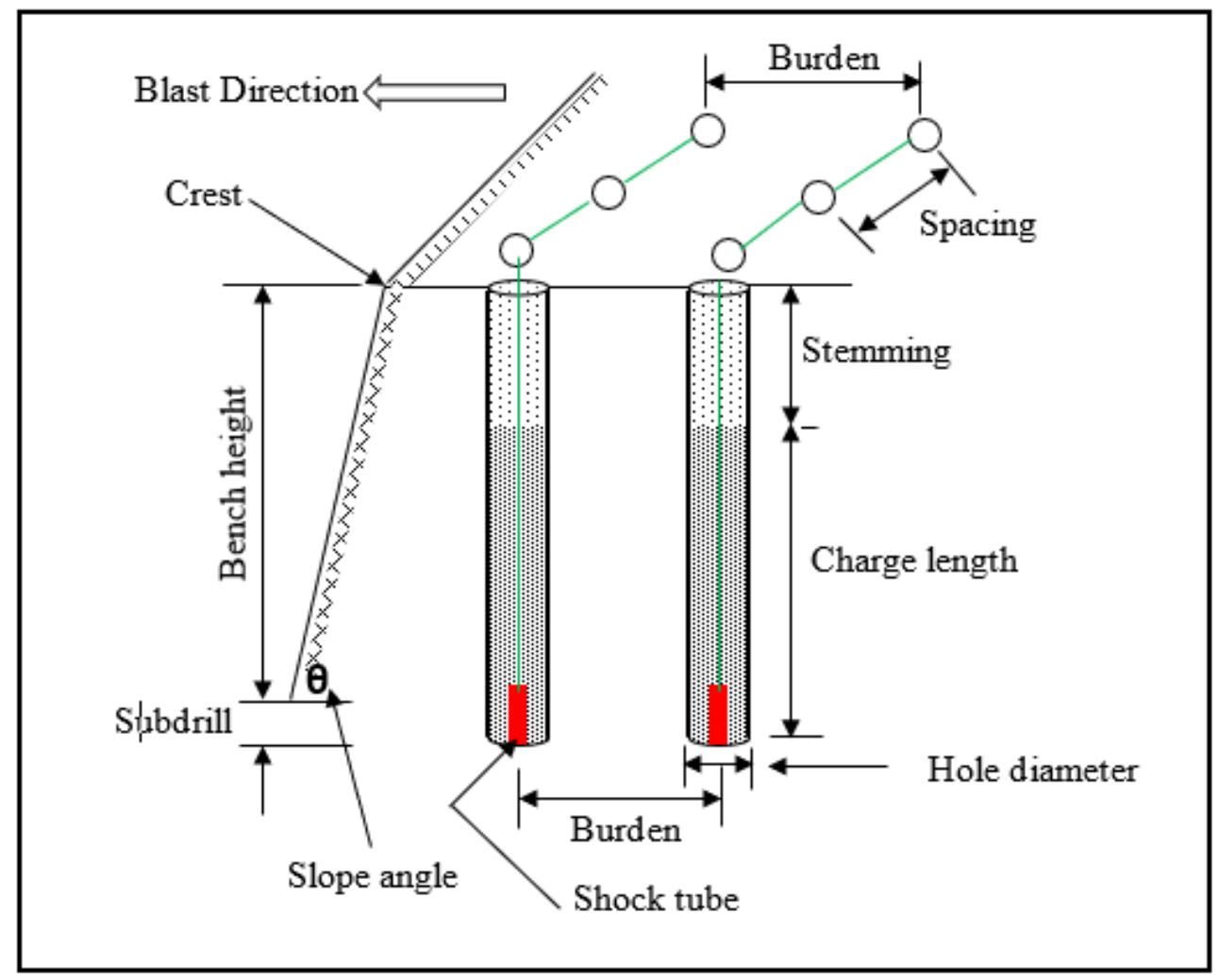

Figure 2. Cross section of blastholes

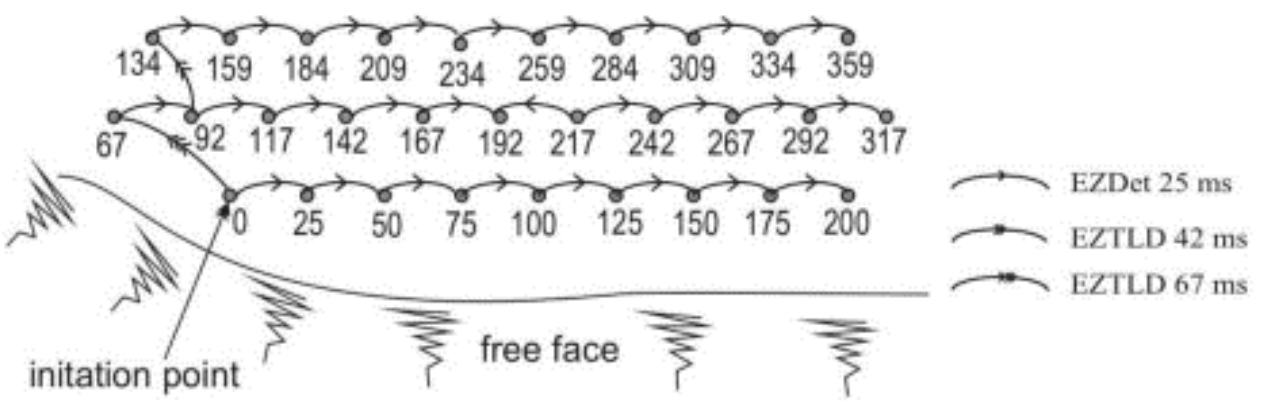

Figure 3. Typical firing pattern used in Lafarge Kanthan Quarry

Blastholes were drilled based on staggered pattern with depth between 11.0 to $12.7 \mathrm{~m}$. Bulk explosives were used as the blasting agent with the open cup density of $1.05 \mathrm{~g} / \mathrm{cm}^{3}$ and velocity of detonation of $5,800 \mathrm{~m} / \mathrm{s}$ at $89 \mathrm{~mm}$ diameter. All the blastholes are of diameter 89 $\mathrm{mm}$.

\section{Fragmentation Analysis}

The digital image analysis technique was used to analyse the various sizes of the blasted fragments produced due to its simplicity, cost effectiveness and lesser time taken [1]. The WipFrag software was used for this purpose. Six different blasting events were analysed. The images of blasted muck piles were captured using digital camera and uploaded into the wipFrag software through a suitable data cable. The images were scaled using a pole of known length $1.5 \mathrm{~m}$. Filtering and edge detection were carried out to generate net. The graphs of particle size distribution were then obtained. Figure 4(a-f) shows the captured muckpile and the coloured netting generated for each muckpile for the six blast events. 


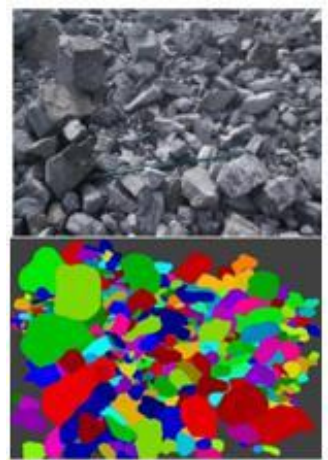

a. Blast event 1

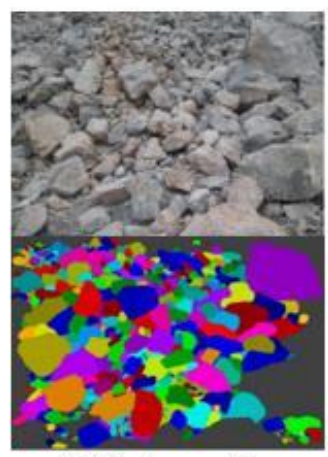

d. Blast event 4

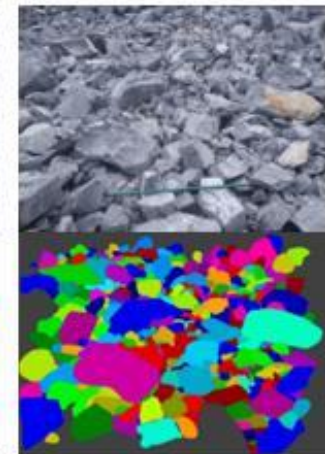

b. Blast event 2

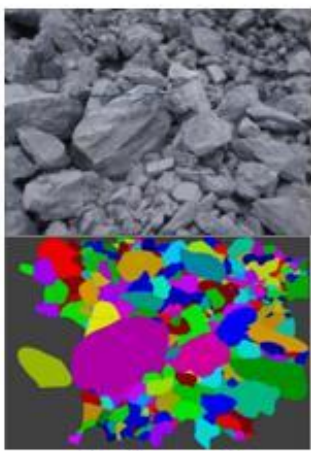

e. Blast event 5

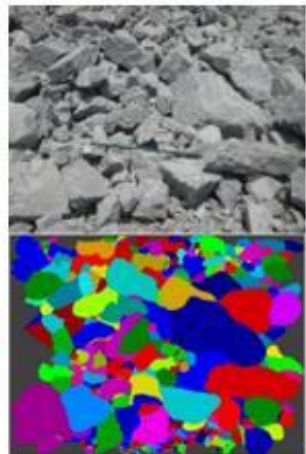

c. Blast event 3

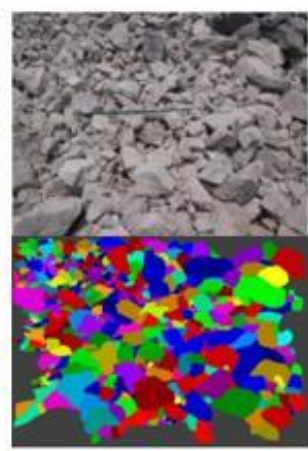

f. Blast event 6

Figure 4. Captured muckpiles and their nettings

\section{Powder Factor}

Powder factor is expressed as the weight of explosives used to blast a given volume of rock. Equation 1 was used to calculate the powder factor in each blast.

$$
\text { Powder factor }=\frac{\text { Weight of explosive per blasthole }(\mathrm{kg})}{\text { Volume of rock blasted per hole }\left(\mathrm{m}^{3}\right)}
$$

The quantity of explosive used per hole is the summation of booster or primer charge $(P)$ and column charge $(Q)$ (Equation 2).

$$
\text { Explosive per hole }=\text { primer } \operatorname{charge}(P)+\operatorname{column} \operatorname{charge}(Q)
$$

The amount of explosive utilized as column (booster) charge in kilogram was calculated using Equation 3:

$$
\text { Column Charge }=\frac{1}{4} \pi D^{2} \times Q L \times \rho
$$

where $D$ is the blast hole diameter (m); $Q L$ is charged length (m); and $\rho$ is the density of explosive $\left(\mathrm{kg} / \mathrm{m}^{3}\right)$. The volume of rock broken per hole was estimated with Equation 4.

$$
\text { Vol. of broken rock per hole }=S \times B \times B H
$$

where $S$ is the spacing $(\mathrm{m}) ; B$ is burden $(\mathrm{m})$; and $B H$ is the bench height $(\mathrm{m})$. The bench height was taken as the difference between the hole depth $(L)$ and the Sub drill length $(S D)$ (Equation 5).

$$
B H=L-S D
$$




\section{The Point Load and the Uniaxial Compressive Strength (UCS)}

The point load test was used as an indirect measure of the compressive strength of the studied rocks to determine point strength index, $\left(\mathrm{I}_{\mathrm{s} 50}\right)$. The test was performed by subjecting a rock specimen to an increasingly concentrated load until failure occurs by splitting the specimen.

Ten samples of rock from each blast area were tested to obtain a mean point load index value. Irregular rock samples of diameters $50 \pm 35 \mathrm{~mm}$ and of suitable shapes were selected for point load test. The irregular lumps were shaped by cutting so that the diameter to length ratio exceeds 1.0. The test procedure was in accordance to suggested methods by the International Society of Rock Mechanics (ISRM) [16] and the American Society for Testing and Materials (ASTM) [17]. The uncorrected point load strength value $\left(I_{S}\right)$ was converted to corrected point load $\left(I_{s 50}\right)$ as suggested by Broch and Franklin [18].

The uniaxial compressive strength (UCS) in MPa was evaluated from corrected point load strength $\left(I_{s 50}\right)$ using Equation (6) as recommended by [19].

$$
U C S=I_{S 50} \times(14 \sim 16)=\left[I_{S} \times\left(\frac{D_{e}}{50}\right)^{0.45}\right] \times(14 \sim 16)
$$

where $I_{S}(\mathrm{MPa})$ is the uncorrected point load and De is the equivalent core diameter $(\mathrm{mm})$.

\section{Results and Discussion}

\section{Drill and Blast Parameters}

Table 1 shows the drill and blast design parameters as obtained from each blast event. The powder factor varies from 0.34 to $0.43 \mathrm{~kg} / \mathrm{m}^{3}$ while the quantity of explosive detonated per blast hole varies from $54.91 \mathrm{~kg}$ to $67.73 \mathrm{~kg}$. All the six blast events have same burden of 3.5 $\mathrm{m}$ and a constant subdrill of $1 \mathrm{~m}$. Figure 2 and Equation 2 to 5 explained the parameters of Table 1.

Table 1. Drill and Blast Design Parameters

\begin{tabular}{lcccccc}
\hline \multicolumn{1}{c}{ Parameters } & Blast l & Blast 2 & Blast 3 & Blast 4 & Blast 5 & Blast 6 \\
\hline Number of holes & 60 & 58 & 60 & 52 & 50 & 54 \\
Hole diameter $(\mathrm{mm})$ & 89 & 89 & 89 & 89 & 89 & 89 \\
Hole depth $(\mathrm{m})$ & 11.0 & 11.0 & 11.6 & 12.7 & 12.5 & 12.0 \\
Burden $(\mathrm{m})$ & 3.5 & 3.5 & 3.5 & 3.5 & 3.5 & 3.5 \\
Spacing $(\mathrm{m})$ & 4.5 & 4.5 & 4.0 & 4.5 & 4.0 & 4.5 \\
Stemming $(\mathrm{m})$ & 4.0 & 4.0 & 4.0 & 4.5 & 4.0 & 4.5 \\
Sub-drill $(\mathrm{m})$ & 1 & 1 & 1 & 1 & 1 & 1 \\
Volume blasted $\left(\mathrm{m}^{3}\right)$ & 9450.0 & 9135.0 & 8904.0 & 9582.3 & 8050.0 & 9355.5 \\
Density $\left(\mathrm{g} / \mathrm{cm}^{3}\right)$ & 2.6 & 2.6 & 2.6 & 2.6 & 2.6 & 2.6 \\
Tonnage blasted $(\mathrm{g})$ & 24570.0 & 23751.0 & 23150.4 & 24914.0 & 20930.0 & 24324.3 \\
Total explosive used $(\mathrm{kg})$ & 4063.5 & 3562.7 & 3294.5 & 3258.0 & 2898.0 & 3555.5 \\
Explosive per hole $(\mathrm{kg} / \mathrm{hole})$ & 67.73 & 61.43 & 54.91 & 62.65 & 57.96 & 65.84 \\
Explosive per meter $(\mathrm{kg} / \mathrm{m})$ & 9.68 & 8.78 & 7.22 & 7.64 & 6.82 & 8.78 \\
Powder factor $\left(\mathrm{kg} / \mathrm{m}^{3}\right)$ & 0.43 & 0.39 & 0.37 & 0.34 & 0.36 & 0.38 \\
\hline \hline
\end{tabular}

\section{Percentage Cumulative Particle Size of Muckpiles}

Figure 5 to 10 display the particle size distribution analysis chart obtained from the wipFrag software for each blast event. Fundamentally, each of the figures contains four main parts. To the left is the chart box that contains salient measurement information - the minimum particle size, the maximum size, the mean size, some percentage passing sizes, and standard 
deviation amongst others. To the left are the sieve sizes and the corresponding cumulative percentage passing values. The central part of the chart contains a blue line that represents the cumulative percentage passing curve, and a red histogram that outlines the percentage passing value for each size class. The horizontal axis (sieve size) is on a log scale for clarity purposes.

Location: Kanthan Quarry Bench: 185

WipFrag 2.7.28 Hazizan-PPKBSM USM - 734282061169653276

$B 1$ (2) March 06, 2018, 06:56:42 PM Malay Peninsula Standard Time

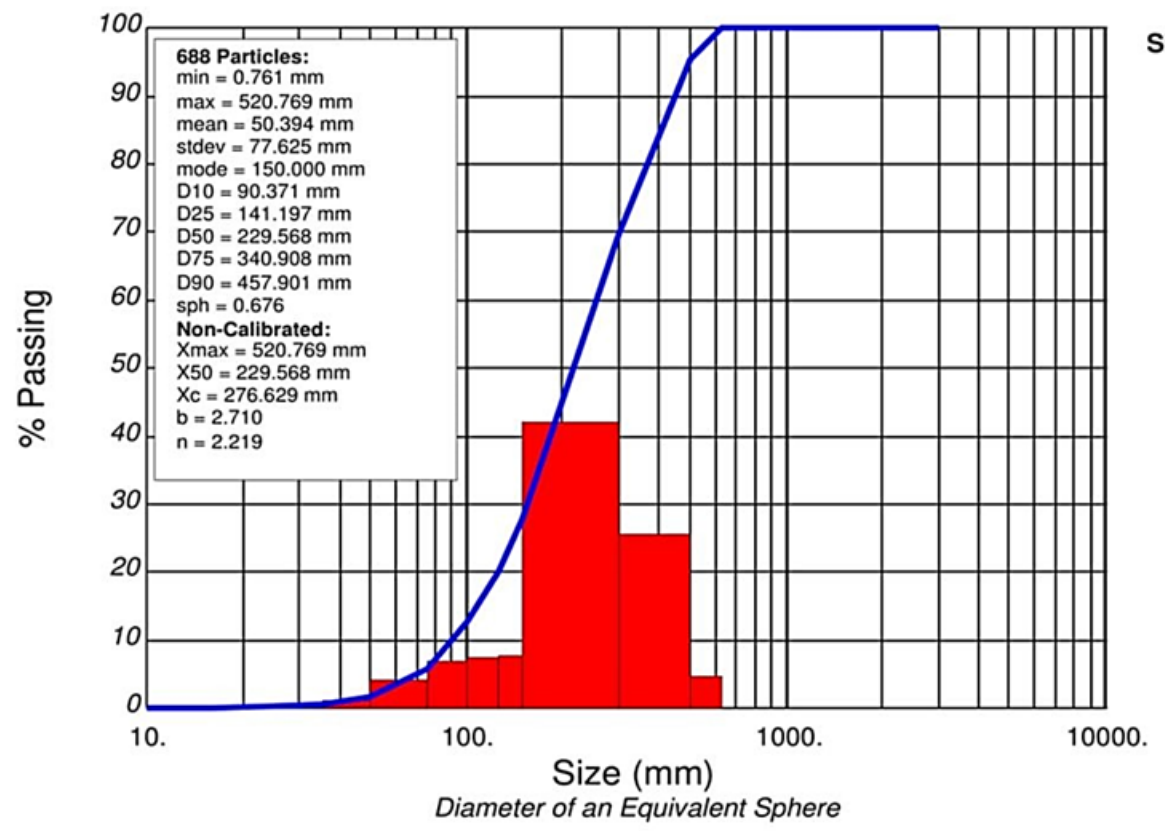

$\begin{array}{rr}\text { Size (mm) } & \text { \% Passing } \\ 3000.00 & 100.00 \% \\ 1500.00 & 100.00 \% \\ 1000.00 & 100.00 \% \\ 625.00 & 100.00 \% \\ 500.00 & 95.40 \% \\ 300.00 & 69.76 \% \\ 150.00 & 27.68 \% \\ 125.00 & 20.06 \% \\ 100.00 & 12.62 \% \\ 75.00 & 5.82 \% \\ 50.00 & 1.76 \% \\ 35.50 & 0.52 \% \\ 25.00 & 0.21 \% \\ 16.00 & 0.06 \% \\ 12.50 & 0.05 \% \\ 10.00 & 0.04 \% \\ 8.00 & 0.03 \% \\ 6.70 & 0.02 \% \\ 5.60 & 0.02 \% \\ 4.75 & 0.02 \% \\ 4.00 & 0.01 \% \\ 3.35 & 0.01 \% \\ 2.00 & 0.00 \%\end{array}$

Figure 5. Particle size distribution analysis for blast event 1

Location: Kanthan Quarry Bench: 185

WipFrag 2.7.28 Hazizan - PPKBSM USM - 734282061169653276

B2 March 06, 2018, 07:54:54 PM Malay Peninsula Standard Time

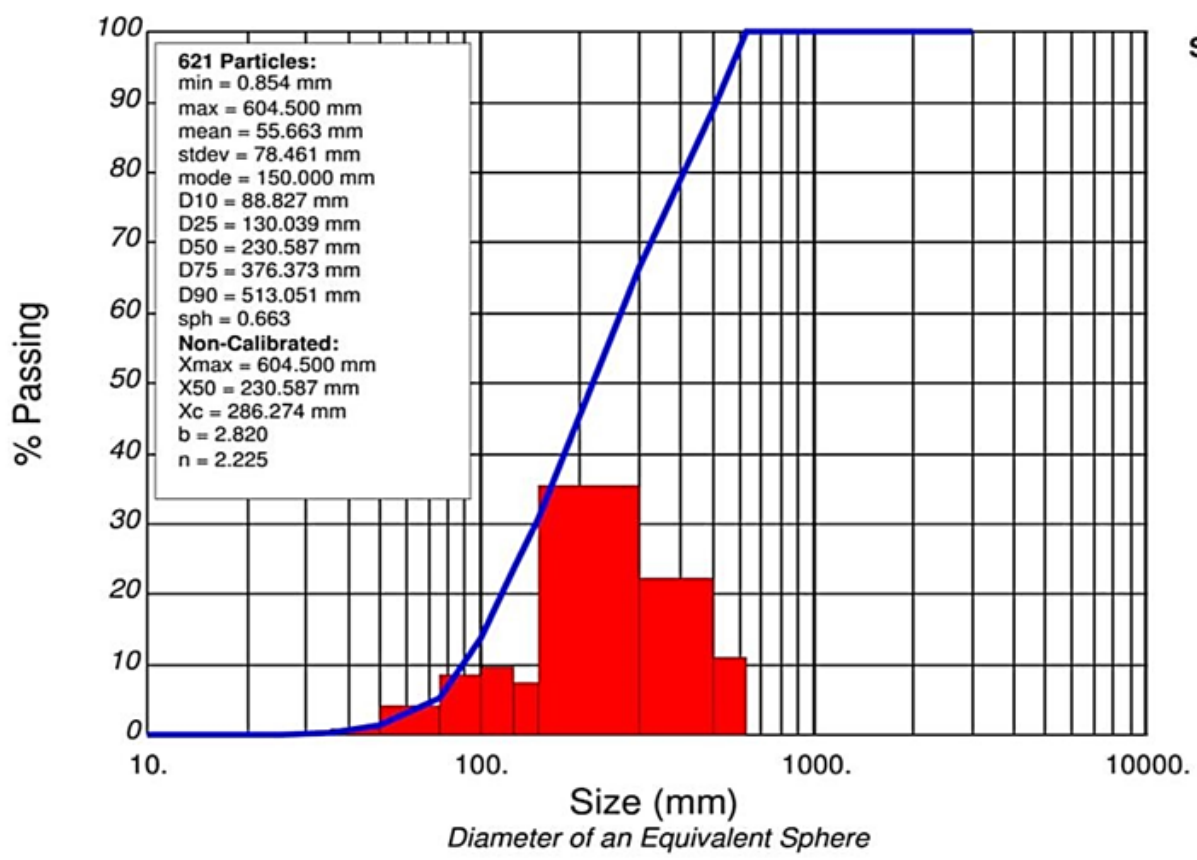

$\begin{array}{rr}\text { Size (mm) } & \text { \% Passing } \\ 3000.00 & 100.00 \% \\ 1500.00 & 100.00 \% \\ 1000.00 & 100.00 \% \\ 625.00 & 100.00 \% \\ 500.00 & 88.83 \% \\ 300.00 & 66.45 \% \\ 150.00 & 30.90 \% \\ 125.00 & 23.51 \% \\ 100.00 & 13.78 \% \\ 75.00 & 5.33 \% \\ 50.00 & 1.32 \% \\ 35.50 & 0.36 \% \\ 25.00 & 0.11 \% \\ 16.00 & 0.07 \% \\ 12.50 & 0.04 \% \\ 10.00 & 0.03 \% \\ 8.00 & 0.02 \% \\ 6.70 & 0.01 \% \\ 5.60 & 0.01 \% \\ 4.75 & 0.01 \% \\ 4.00 & 0.01 \% \\ 3.35 & 0.01 \% \\ 2.00 & 0.01 \%\end{array}$

Figure 6. Particle size distribution analysis for blast event 2 
Location: Kanthan Quarry Bench: 165

WipFrag 2.7.28 Hazizan-PPKBSM USM - 734282061169653276

B3 01 (1) March 06, 2018, 11:22:01 PM Malay Peninsula Standard Time

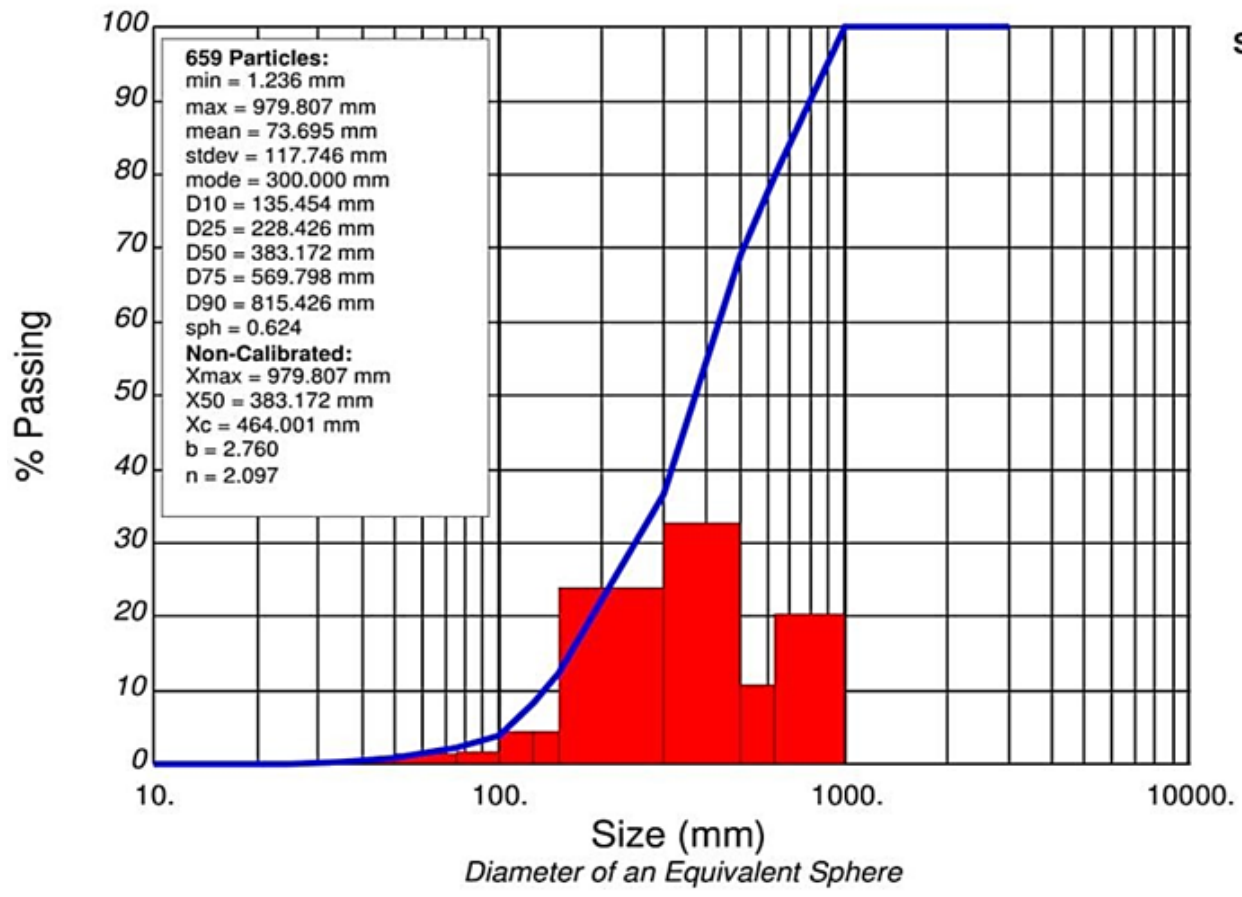

$\begin{array}{rr}\text { Size }(\mathbf{m m}) & \text { \% Passing } \\ 3000.00 & 100.00 \% \\ 1500.00 & 100.00 \% \\ 1000.00 & 100.00 \% \\ 625.00 & 79.68 \% \\ 500.00 & 69.08 \% \\ 300.00 & 36.42 \% \\ 150.00 & 12.49 \% \\ 125.00 & 8.21 \% \\ 100.00 & 3.84 \% \\ 75.00 & 2.30 \% \\ 50.00 & 0.85 \% \\ 35.50 & 0.35 \% \\ 25.00 & 0.13 \% \\ 16.00 & 0.05 \% \\ 12.50 & 0.03 \% \\ 10.00 & 0.02 \% \\ 8.00 & 0.01 \% \\ 6.70 & 0.01 \% \\ 5.60 & 0.01 \% \\ 4.75 & 0.01 \% \\ 4.00 & 0.01 \% \\ 3.35 & 0.01 \% \\ 2.00 & 0.00 \% \\ & \end{array}$

Figure 7. Particle size distribution analysis for blast event 3

Location: Kanthan Quarry Bench: 180

WipFrag 2.7.28 Hazizan - PPKBSM USM - 734282061169653276

IMG20180301134707 March 07, 2018, 04:28:15 PM Malay Peninsula Standard Time

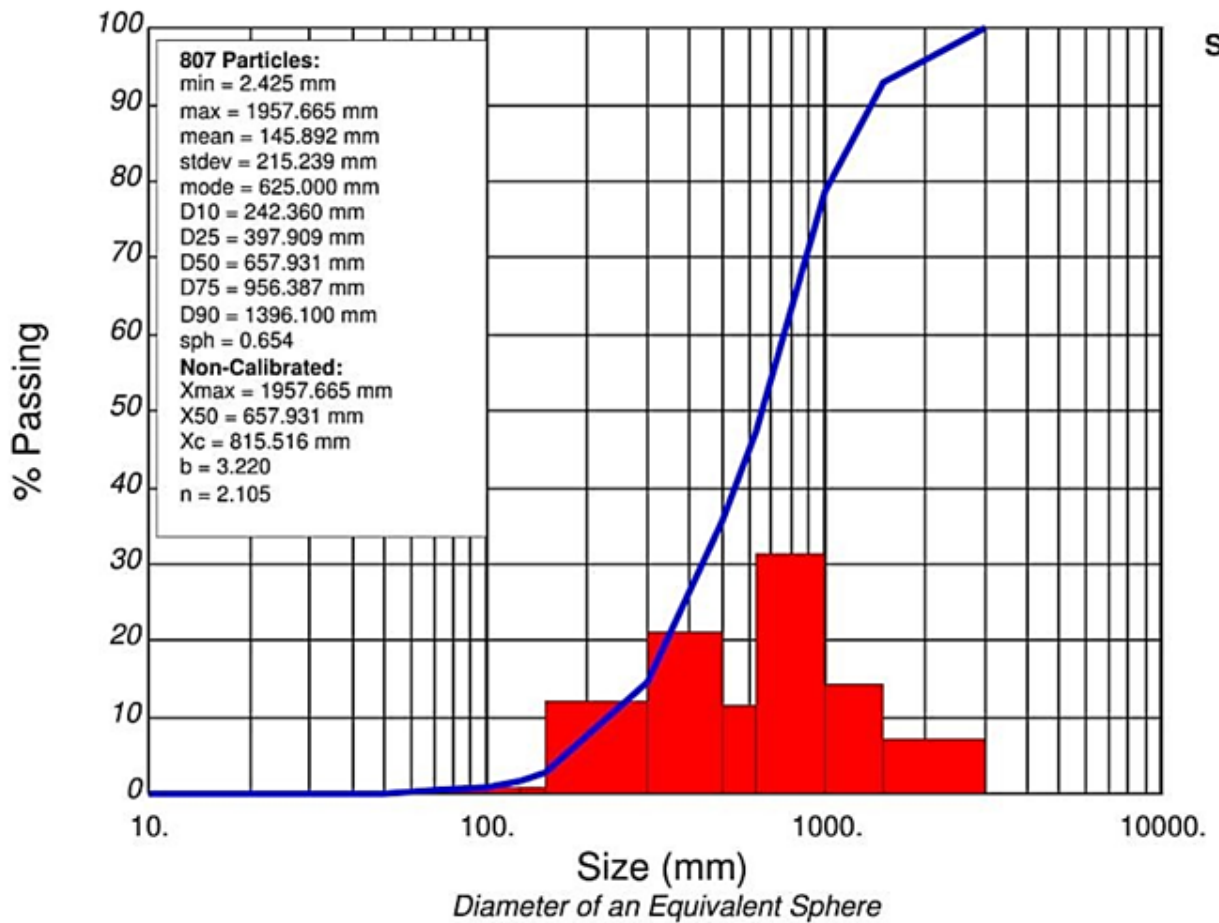

$\begin{array}{rr}\text { Size }(\mathbf{m m}) & \text { \% Passing } \\ 3000.00 & 100.00 \% \\ 1500.00 & 92.98 \% \\ 1000.00 & 78.65 \% \\ 625.00 & 47.24 \% \\ 500.00 & 35.82 \% \\ 300.00 & 14.63 \% \\ 150.00 & 2.59 \% \\ 125.00 & 1.67 \% \\ 100.00 & 0.99 \% \\ 75.00 & 0.42 \% \\ 50.00 & 0.13 \% \\ 35.50 & 0.05 \% \\ 25.00 & 0.02 \% \\ 16.00 & 0.01 \% \\ 12.50 & 0.01 \% \\ 10.00 & 0.01 \% \\ 8.00 & 0.01 \% \\ 6.70 & 0.01 \% \\ 5.60 & 0.00 \% \\ 4.75 & 0.00 \% \\ 4.00 & 0.00 \% \\ 3.35 & 0.00 \% \\ 2.00 & 0.00 \%\end{array}$

Figure 8. Particle size distribution analysis for blast event 4 
Location: Kanthan Quarry Bench: 180

WipFrag 2.7.28 Hazizan-PPKBSM USM - 734282061169653276

IMG20180301134927 March 08, 2018, 02:23:10 AM Malay Peninsula Standard Time

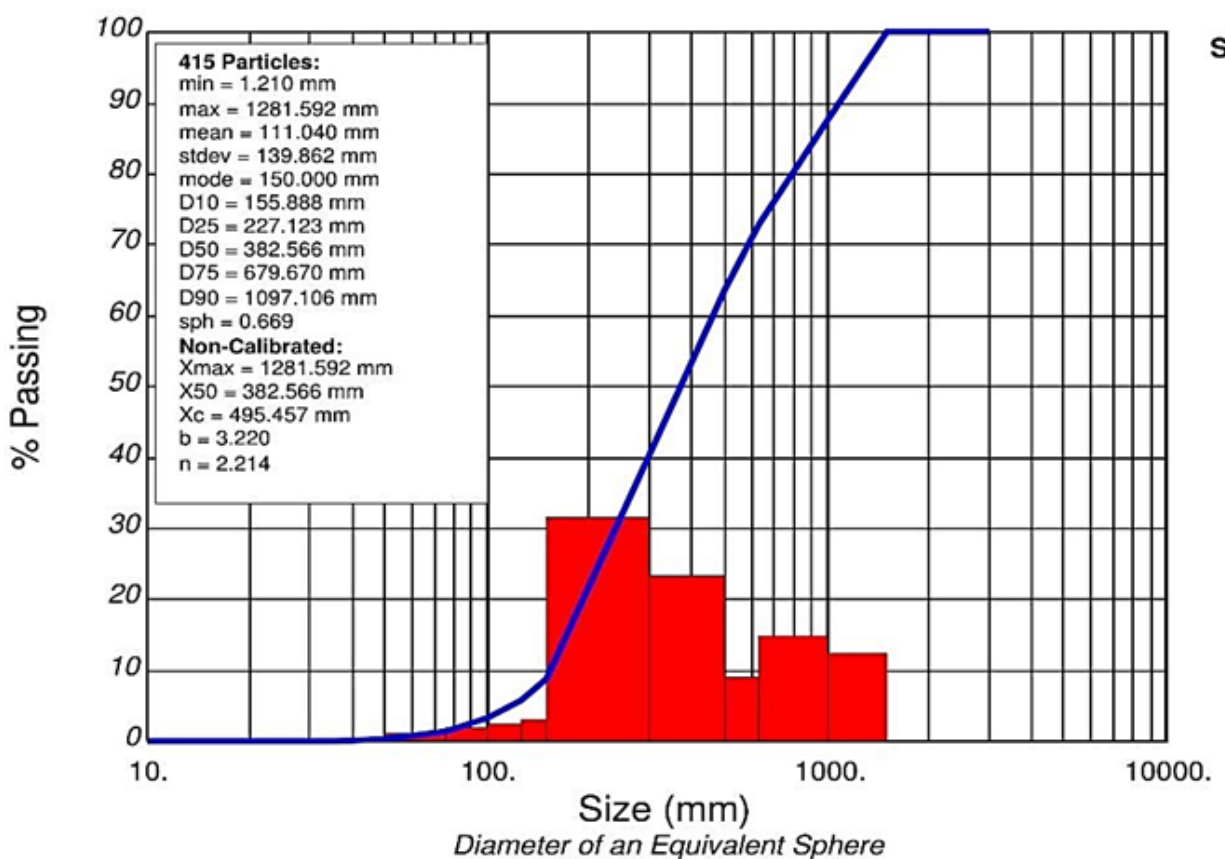

$\begin{array}{rr}\text { Size }(\mathbf{m m}) & \% \text { Passing } \\ 3000.00 & 100.00 \% \\ 1500.00 & 100.00 \% \\ 1000.00 & 87.59 \% \\ 625.00 & 72.85 \% \\ 500.00 & 63.73 \% \\ 300.00 & 40.35 \% \\ 150.00 & 8.76 \% \\ 125.00 & 5.76 \% \\ 100.00 & 3.34 \% \\ 75.00 & 1.31 \% \\ 50.00 & 0.31 \% \\ 35.50 & 0.09 \% \\ 25.00 & 0.02 \% \\ 16.00 & 0.01 \% \\ 12.50 & 0.01 \% \\ 10.00 & 0.00 \% \\ 8.00 & 0.00 \% \\ 6.70 & 0.00 \% \\ 5.60 & 0.00 \% \\ 4.75 & 0.00 \% \\ 4.00 & 0.00 \% \\ 3.35 & 0.00 \% \\ 2.00 & 0.00 \%\end{array}$

Figure 9. Particle size distribution analysis for blast event 5

Location: Kanthan Quarry Bench: 180

WipFrag 2.7.28 Hazizan - PPKBSM USM - 734282061169653276

IMG20180301135053 March 08, 2018, 04:43:07 PM Malay Peninsula Standard Time

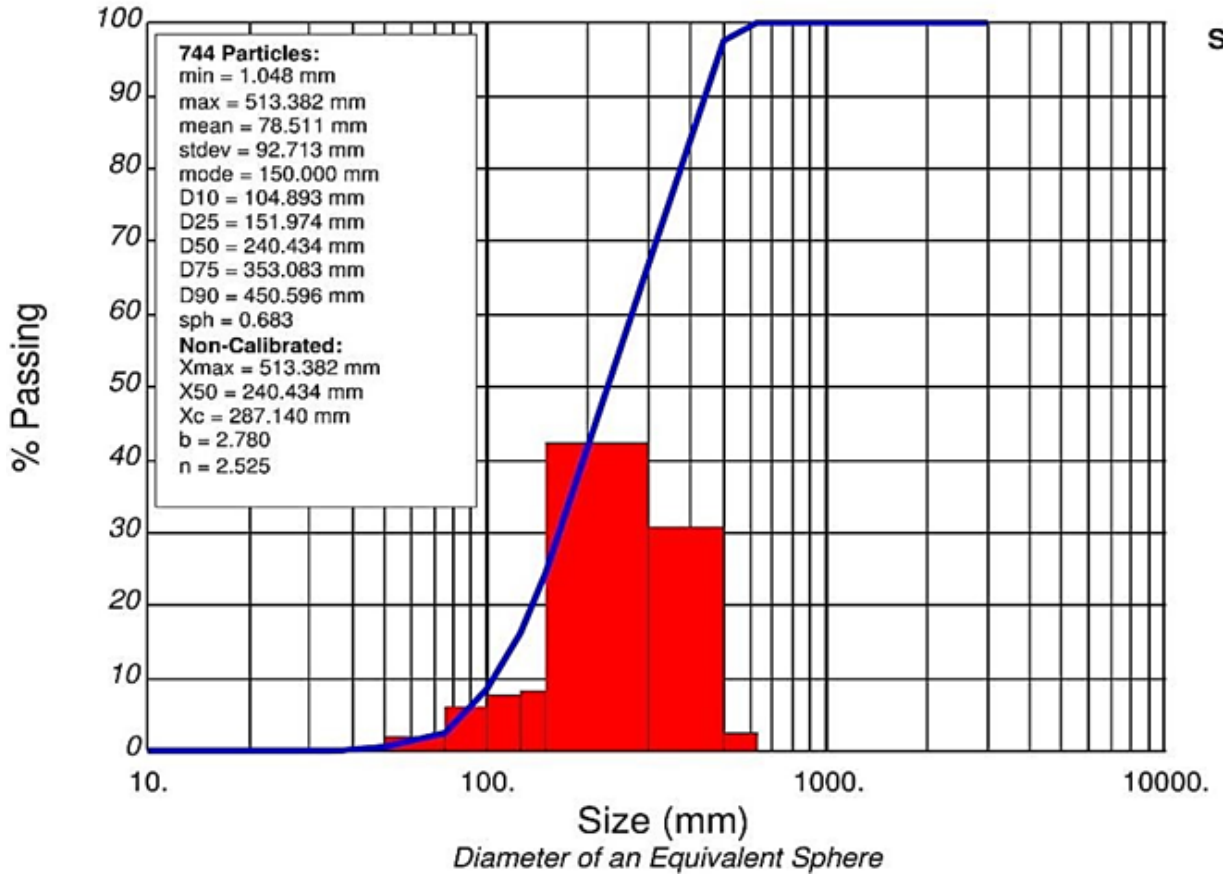

$\begin{array}{rr}\text { Size (mm) } & \text { \% Passing } \\ 3000.00 & 100.00 \% \\ 1500.00 & 100.00 \% \\ 1000.00 & 100.00 \% \\ 625.00 & 100.00 \% \\ 500.00 & 97.60 \% \\ 300.00 & 66.83 \% \\ 150.00 & 24.44 \% \\ 125.00 & 16.17 \% \\ 100.00 & 8.50 \% \\ 75.00 & 2.49 \% \\ 50.00 & 0.56 \% \\ 35.50 & 0.14 \% \\ 25.00 & 0.07 \% \\ 16.00 & 0.02 \% \\ 12.50 & 0.02 \% \\ 10.00 & 0.01 \% \\ 8.00 & 0.01 \% \\ 6.70 & 0.01 \% \\ 5.60 & 0.01 \% \\ 4.75 & 0.01 \% \\ 4.00 & 0.00 \% \\ 3.35 & 0.00 \% \\ 2.00 & 0.00 \% \\ & \end{array}$

Figure 10. Particle size distribution analysis for blast event 6 
The Lafarge Kanthan Quarry uses gyratory crusher with maximum feed size of $1500 \mathrm{~mm}$ as a primary crusher. Table 2 shows the mean fragment and other details of the fragmentation analysis.

Table 2. Details of Particle Size Distribution

\begin{tabular}{lcrrrrr}
\hline \multicolumn{1}{c}{ Parameters } & \multicolumn{1}{c}{ Blast 1 } & \multicolumn{1}{c}{ Blast 2 } & Blast 3 & Blast 4 & Blast 5 & Blast 6 \\
\hline Crusher's opening (mm) & \multicolumn{1}{c}{1500} & 1500 & \multicolumn{1}{c}{1500} & 1500 & 1500 & 1500 \\
Min. fragt. size (mm) & 0.761 & 0.854 & 1.236 & 2.425 & 1.210 & 1.048 \\
Max. fragt. size (mm) & 520.769 & 604.500 & 979.807 & 1957.665 & 1281.592 & 513.382 \\
Mean Fragt. size (mm) & 50.394 & 55.663 & 73.695 & 145.892 & 111.040 & 78.511 \\
D10 (mm) & 90.371 & 88.827 & 135.454 & 242.360 & 155.888 & 104.893 \\
D25 (mm) & 141.197 & 130.039 & 228.426 & 397.909 & 227.123 & 151.974 \\
D50 (mm) & 229.568 & 230.587 & 383.172 & 657.931 & 382.566 & 240.434 \\
D75 (mm) & 340.908 & 376.373 & 569.796 & 956.387 & 679.670 & 353.083 \\
D90 (mm) & 457.901 & 513.051 & 815.426 & 1396.100 & 1097.106 & 450.596 \\
Uniformity index (n) & 2.219 & 2.225 & 2.097 & 2.105 & 2.214 & 2.525 \\
\% passing at 1500 mm & 100.00 & 100.00 & 100.00 & 92.98 & 100.00 & 100.00 \\
Assessment & Good & Good & Good & Good & Good & Good \\
\hline \hline
\end{tabular}

The Table shows the minimum, maximum, and the mean fragment sizes obtained from each blast. D10, D25, D50, D75, and D90 represent the sieve sizes through which 10\%, $25 \%, 50 \%, 75 \%$, and $90 \%$ of the blasted materials will pass through respectively. The uniformity index (n) measures the closeness of fragments produced to the mean size [20], [21].

The mean fragment size obtained for all the six blast events ranges from 50.39 to $145.89 \mathrm{~mm}$. The maximum fragment sizes obtained for five blasts were below the primary crusher's gape of $1500 \mathrm{~mm}$ which gives $100 \%$ passing and $0 \%$ boulders except in blast event 4 with maximum fragment size of $1957.67 \mathrm{~mm}$ that gave rise to $92.98 \%$ passing and $7.02 \%$ boulders formation. The uniformity index from the six events are greater than 2.00 which is an indication of good proportions of the mixtures of the various size fragments

\section{Blast Design Factors and Mean Fragmentation Size}

Table 3 shows the design parameters, the average uniaxial compressive strength (UCS) for each blasted quarry face, and the mean fragment size of the corresponding muckpile for the six blast events.

Table 3. Design parameters, UCS and Mean Fragment Size

\begin{tabular}{cccccc}
\hline $\begin{array}{l}\text { Blast } \\
\text { Event }\end{array}$ & $\begin{array}{l}\text { Spacing: } \\
\text { Burden }\end{array}$ & $\begin{array}{l}\text { Stiffness } \\
\text { Ratio }\end{array}$ & $\begin{array}{l}\text { Powder Factor } \\
\left(\mathbf{k g} / \mathbf{m}^{\mathbf{3}}\right)\end{array}$ & $\begin{array}{l}\text { UCS } \\
(\mathbf{M P a})\end{array}$ & $\begin{array}{l}\text { Mean Frag. } \\
\text { Size }(\mathbf{m m})\end{array}$ \\
\hline 1 & 1.29 & 2.86 & 0.43 & 98.55 & 50.39 \\
2 & 1.29 & 2.86 & 0.39 & 95.73 & 55.66 \\
3 & 1.14 & 3.03 & 0.37 & 84.76 & 73.70 \\
4 & 1.29 & 3.34 & 0.34 & 60.95 & 145.89 \\
5 & 1.14 & 3.29 & 0.36 & 76.83 & 111.04 \\
6 & 1.29 & 3.14 & 0.38 & 92.70 & 78.51 \\
\hline \hline
\end{tabular}

The average uniaxial compressive strength varies from 60.95 to $98.55 \mathrm{MPa}$ which confirmed the work of Simon et al. [15] that the rock is weathered and falls into the category of medium hard rocks. Blast event 1 has the highest powder factor of $0.43 \mathrm{~kg} / \mathrm{m}^{3}$ and smallest mean fragment size of $50.39 \mathrm{~mm}$, while blast event 4 has the smallest powder factor of 0.34 $\mathrm{kg} / \mathrm{m}^{3}$ with the highest mean fragment size of $145.89 \mathrm{~mm}$. 
Figure 11 to 14 show the relationship between the evaluated blast design factors and the mean fragment size obtained.

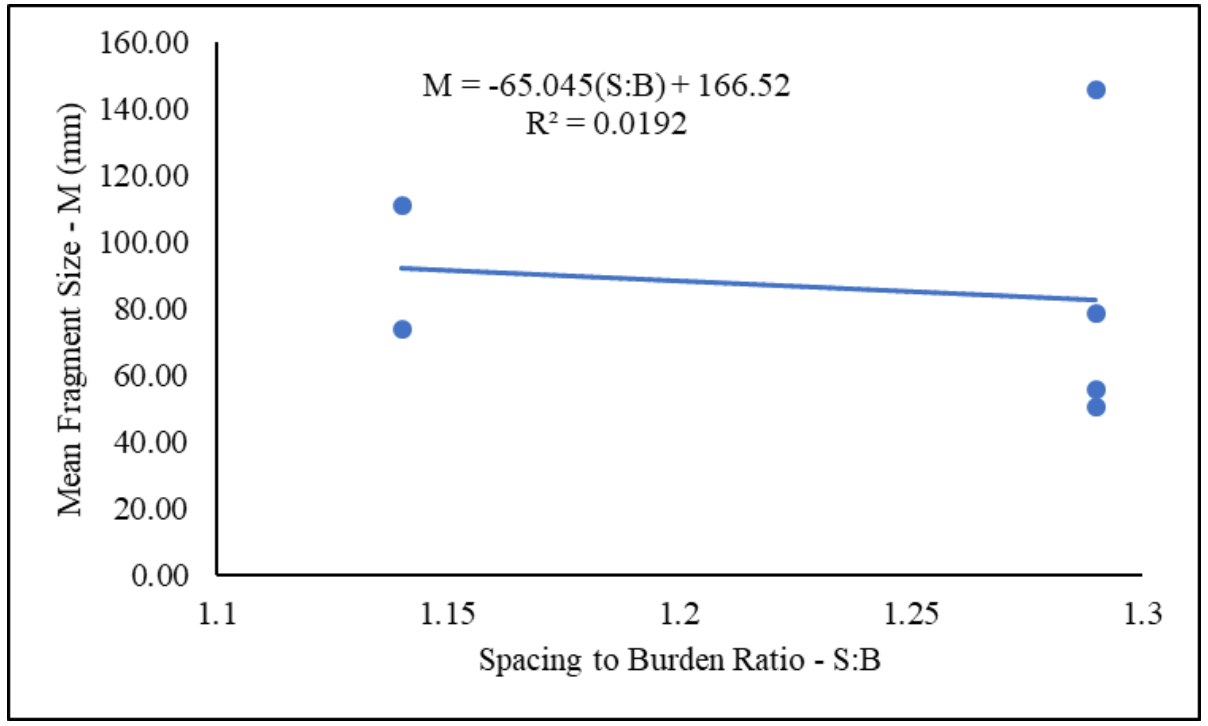

Figure 11. Regression analysis of mean fragment size and spacing-burden ratio

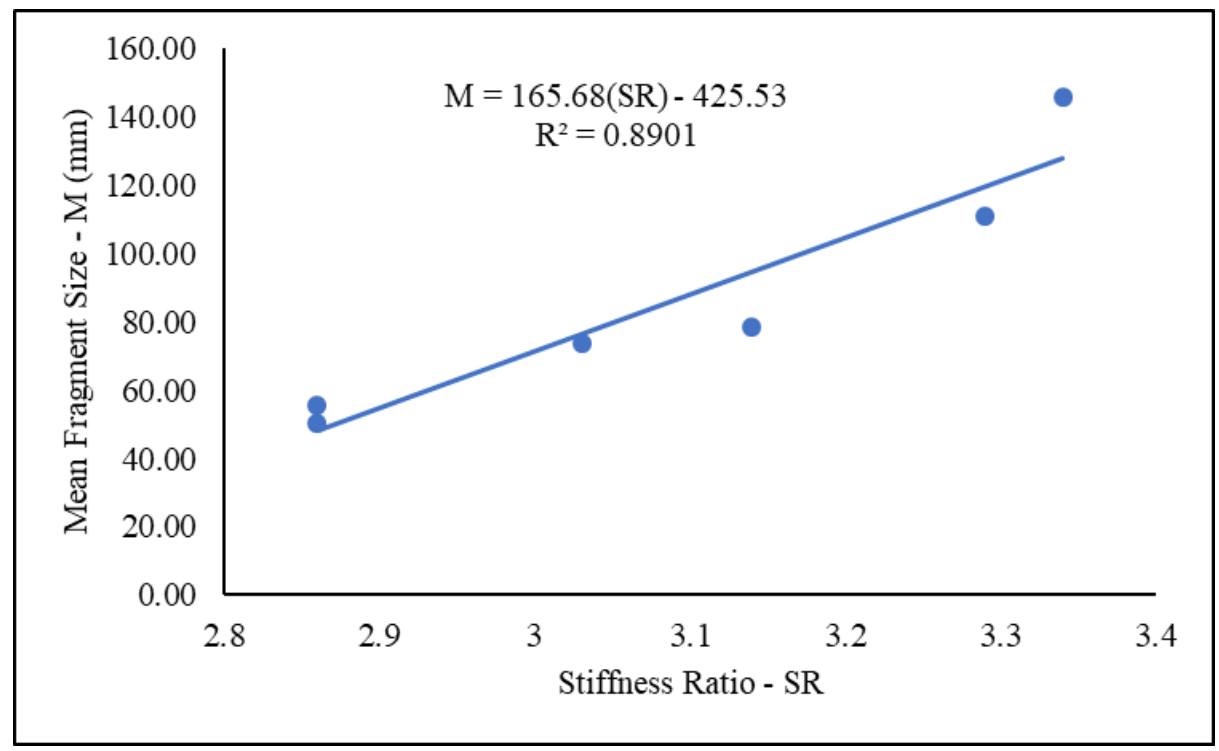

Figure 12. Regression analysis of mean fragment size and stiffness ratio

Figure 11 shows that the ratio of spacing to burden is insignificant in determining the mean fragment size of a blast design. In Table 3, blast 1, 2 and 4 have the same spacing to burden ratio of 1.29 but the mean fragment sizes differ. The much coarser fragment size of blast $4(145.89 \mathrm{~mm})$ as compared to blast $1(50.39 \mathrm{~mm})$ and blast $2(55.66 \mathrm{~mm})$ of the same spacing to burden ratio can be attributed to low powder factor (Table 3). Thus, the spacing to burden ratio is not highly related to the mean fragment size produced. However, adequate burden prevents the rapid release of gases to the atmosphere that can result into air blasts and poor fragmentation while good spacing prevents excessive crushing and inadequate fracturing [12]. 


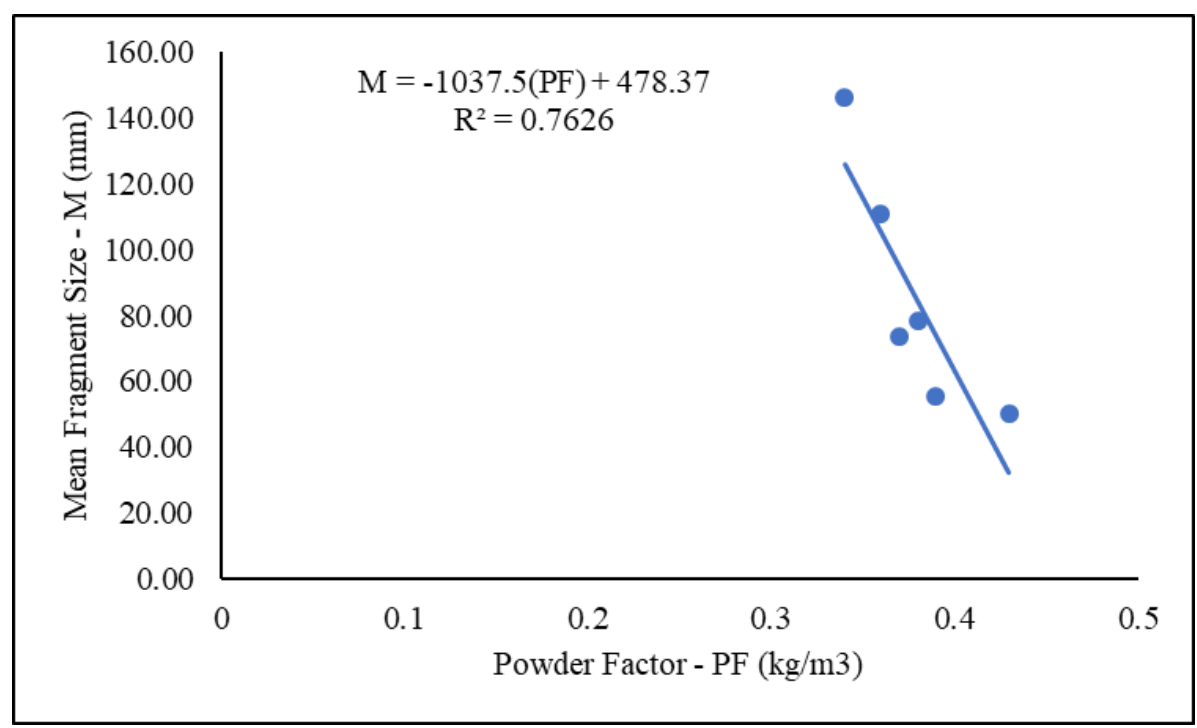

Figure 13. Regression analysis of mean fragment size and powder factor

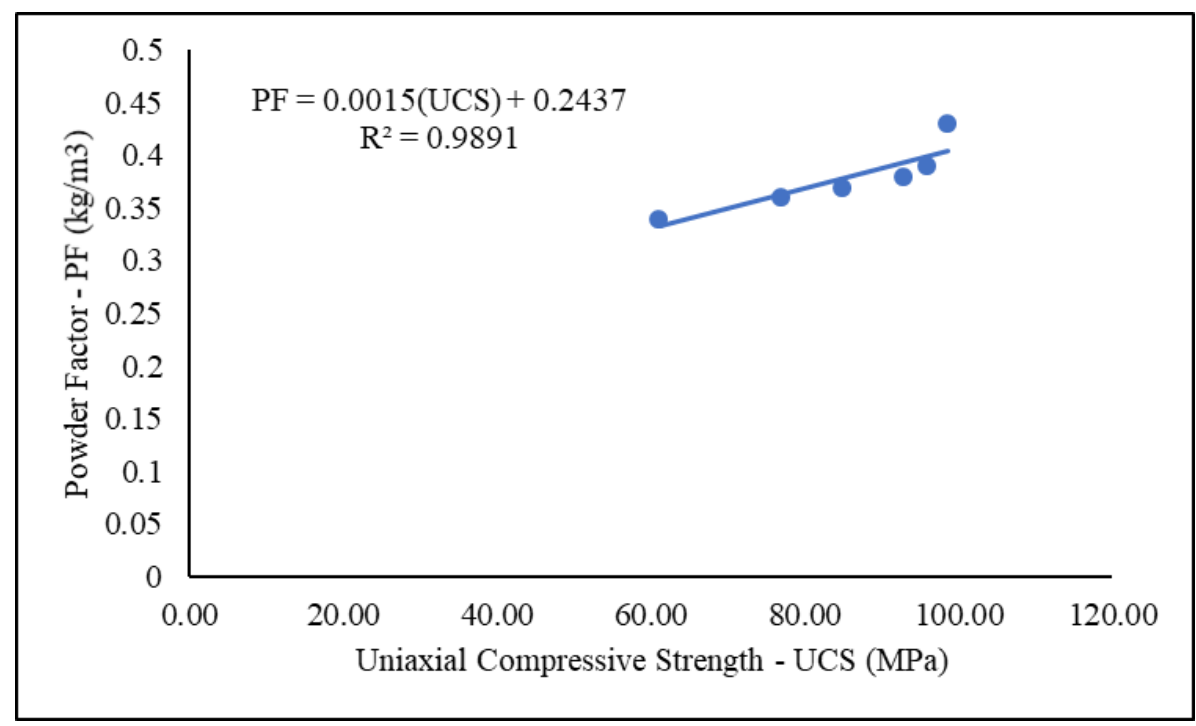

Figure 14. Regression analysis of powder factor and UCS

The ratio of bench height to burden is called the stiffness ratio. Figure 12 shows that the stiffness ratio significantly affects the mean fragment size with a correlation coefficient of 0.89 . The higher the value of the stiffness ratio, the coarser the mean fragment size becomes. Unnecessary and excessive large value of this ratio will lead to poor fragmentation.

Figure 13 shows a correlation coefficient of 0.76 between the powder factor and the mean fragment size. This implies that mean fragment size strongly depends on the quantity of explosive used in a blast. The higher the value of the powder factor, the smaller and finer the mean fragment size becomes. Nevertheless, the quantity of explosive to be used in a blast design is significantly dictated by the size of the hole diameter, the strength characteristics of rock and water condition. The results agreed with the work of [6], [12] and [22]. 
In Figure 14, the required powder factor was correlated with uniaxial compressive strength (UCS). The regression analysis shows a correlation coefficient of 0.99 . Thus, the amount of explosive required to blast a rock is largely a function of its strength characteristics. The powder factor increases with uniaxial compressive strength. Therefore, rock strength is a crucial factor that must be evaluated in any rock blasting design.

\section{Conclusions}

The influence of blast design factors on the mean fragment size has been studied. The stiffness ratio, the powder factor and the strength of rocks are principal factors controlling the size of fragment obtained in a blast design. The mean fragment size increases with stiffness ratio but decreases with higher amount of powder factor. The amount of powder factor required to obtain a given mean fragment size increases with the uniaxial compressive strength. The higher the powder factor, the finer the mean fragment size becomes. However, the ratio of spacing to burden does not significantly affect the mean fragment size obtained.

A powder factor of 0.34 to $0.43 \mathrm{~kg} / \mathrm{m}^{3}$, burden of $3.5 \mathrm{~m}$ and spacing of 4.0 or $4.5 \mathrm{~m}$ as used at Lafarge Kanthan Quarry in this study produced a cumulative percentage passing of 92.8 to $100 \%$ for all the six blast events. The $7.2 \%$ boulder recorded only occurred in one blast event. The mean fragment size obtained in all the events ranges from 50.39 to 145.89 $\mathrm{mm}$ while the opening of the primary crusher is set at $1500 \mathrm{~mm}$. Thus, all the blast events assessed produced good fragmentation.

Only six blast events were studied and analyzed in this research for a preliminary assessment. Further detail research involving a large number of blast events is required to contribute to the position of this research for the studied quarry based on their current practices and geological conditions. Uniaxial compressive strength is not the only rock factor influencing fragmentation. Further research should also include other rock mass properties, spacing and orientation of discontinuities, and the influence of explosives characteristics on fragmentation.

\section{Acknowledgment}

The authors wish to acknowledge the Universiti Sains Malaysia for the financial support through the grant number 1001/PBAHAN/8014043.

\section{References}

[1] B.S. Choudhary, "Firing patterns and its effect on muckpile shape parameters and fragmentation in quarry blasts," International Journal of Research in Engineering and Technology, Vol. 02, No. 9, pp. 32-45, 2013.

[2] B. Elevli, I. Topal, and S. Elevli, "Multivariate statistics application in development of blast fragmentation charts for different rock formations in quarries," Acta Montanistica Slovaca, Vol. 17, No. 4, pp. 300-309, 2012.

[3] S. Prasad, B.S. Choudhary, and A.K. Mishra, "Effect of stemming to burden ratio and powder factor on blast induced rock fragmentation- a case study," IOP Conference Series: Materials Science and Engineering, Vol. 225, 2017, doi: 10.1088/1757-899X/225/1/012191

[4] P.H.S.W. Kulatilake, Q. Wu, T. Hudaverdi, and C. Kuzu, "Mean particle size prediction in rock blast fragmentation using neural networks," Engineering Geology, Vol. 114, No. 3-4, pp. 298-311, 2010, doi: 10.1016/j.enggeo.2010.05.008 
[5] B. Bozic, "Control of fragmentation by blasting," Rudarsko - Geolosko - Naftni Zbornik, Vol. 10, No. 1, pp. 49-57, 1998, doi: UDC 622.235:622.271.2

[6] S.S. Kanchibotla, S. Morrell, W. Valery, and P. O'Loughlin, "Exploring the effect of blast design on SAG mill throughput at KCGM," In: Proceedings of Mine to Mill Conference, Australasian Institute of Mining and Metallurgy, Brisbane, Queensland, pp. 153-158, 1998.

[7] L. Workman, and J. Eloranta, "The effects of blasting on crushing and grinding efficiency and energy consumption," In: Proceedings of $29^{\text {th }}$ Annual Conference on Explosives and Blasting Technique, The International Society of Explosive Engineers, Nashville, Tennessee, pp. 1-5, 2003.

[8] P. Yan, W. Zhou, W. Lu, M. Chen, and C. Zhou, "Simulation of bench blasting considering fragmentation size distribution," International Journal of Impact Engineering, Vol. 90, pp. 132-145, 2016, doi: 10.1016/j.ijimpeng.2015.11.015

[9] P.A. Persson, R. Holmberg, and J. Lee, Rock Blasting and Explosives Engineering, CRC Press, Boca Raton, Florida, United States, 1994, doi: $10.1201 / 9780203740514$.

[10] M. Ruest, P. Cundall, A. Guest, and G. Chitombo, "Developments using the particle flow code to simulate rock fragmentation by condensed phase explosives," In: Proceedings of $8^{\text {th }}$ International Symposium on Rock Fragmentation by Blasting (Fragblast 8), Santiago, Chile, pp. 140-151, 2006.

[11] S.S. Kanchibotla, W. Valery, and S. Morrell, "Modelling fines in blast fragmentation and its impact on crushing and grinding," In: Australasian Institute of Mining and Metallurgy Publication Series: Explo'99: A Conference on Rock Breaking, Australian Institute of Mining and Metallurgy, Kalgoorlie, Western Australia, Australia, pp. 137-144, 1999.

[12] F. Mohamed, A. Hafsaoui, K. Talhi, and K. Menacer, "Study of the powder factor in surface bench blasting," Procedia Earth and Planetary Science, Vol. 15, pp. 892-899, 2015, doi: 10.1016/j.proeps.2015.08.142

[13] P.K. Singh, M.P. Roy, R.K. Paswan, S. Kumar, and R.R. Jha, "Rock fragmentation control in opencast blasting," Journal of Rock Mechanics and Geotechnical Engineering, Vol. 8, No 2, pp. 225-237, 2016, doi: 10.1016/j.jrmge.2015.10.005

[14] R.F. Muhammad, and I. Komoo, "The Kinta Valley karst landscape - a national heritage to be preserved," Geological Society of Malaysia, Vol. 46, pp. 447-453, 2003.

[15] N. Simon, M.F.A. Ghani, A. Hussin, G.T. Lai, A.G. Rafek, N. Surip, T.R.T Monam, and L.K. Ern, "Assessment of rockfall potential of limestone hills in the Kinta Valley," Journal of Sustainability Science and Management, Vol. 10, No. 2, pp. 24-34, 2015.

[16] International Society for Rock Mechanics (ISRM), "Suggested method for determining point load strength," International Journal of Rock Mechanics, Mining Science, and Geomechanics Abstracts, Vol. 22, No 2, pp. 51-60, 1985.

[17] American Society for Testing and Materials (ASTM), "Standard test method for determination of the point load strength index of rock 1," Rock Mechanics, Vol. 22, No. 2, pp. 1-9, 1985.

[18] E. Broch, and J.A. Franklin, "The point load strength test," International Journal of Rock Mechanics and Mining Science, Vol. 9, No. 6, pp. 669-697, 1972.

[19] T.N. Singh, K. Ashutosh, and A. Venkatesh, "Correlation between point load index and uniaxial compressive strength for different rock types," Rock Mechanics and Rock Engineering, Vol. 45, pp. 259-264, 2012. 
[20] C.V.B. Cunningham, "The Kuz-Ram model for prediction of fragmentation from blasting," In: R. Holmberg, and A. Rustan, eds., First International Symposium on Rock Fragmentation, Division of Mining and Rock Excavation, Lulea University of Technology, Lulea, Sweden, pp. 439-454, 1983.

[21] C.V.B. Cunningham, "Fragmentation estimations and the Kuz-Ram model - four years on," In: W.L. Fourney, and R.D. Dick, ed(s)., $2^{\text {nd }}$ International Symposium on Rock Fragmentation by Blasting, Society of Experimental Mechanics, Keystone, Colorado, pp. 475-487, 1987.

[22] P.K. Singh, M.P. Roy, R.K. Pasawan, Md. Sarim, and S. Kumar, "Blast design and fragmentation control - Key to productivity," Journal of Mines, Metals and Fuels, Vol. 63, No. 7, pp. 182-189, 2015. 